\title{
Assessing the Impact COVID-19 Pandemic on the Educational Development of Secondary School Students
}

\author{
Thomas Achoda Omang ${ }^{\mathrm{a}^{*}} \&$ Pius U. Angioha ${ }^{\mathrm{b}}$ \\ ${ }^{a}$ Department of Sociology, University of Calabar,P.M.B 115, Calabar, Cross River State, Nigeria \\ ${ }^{b}$ Department of Sociology, University of Calabar, P.M.B 115, Calabar, Cross River State, Nigeria
}

\begin{abstract}
The current COVID-19 pandemic affecting nearly all nations of the world have had a profound impact on education. In Nigeria, as the cases of infection continue to increase and the extension of measures to curb the spread of the virus now points to the fact that schools are not physically resuming anytime soon. This study examined the extent to which the COVID-19 pandemic measures have affected the educational development of secondary school students in Calabar South Local Government Area of Cross River State, Nigeria. Using the descriptive survey method, data was collected from a sample of 400 samples from a population of 191,630 of Calabar South, Cross River State. The sample size was determined using the Slovin Sample Size Formula. The sample was selected using the stratified, purposive and random sampling technique. the instrument of data collection is a semi-structured questionnaire. Data collected was analysed using descriptive statistics and Simple Lineal Regression at 0.05 level of significance. Result revealed a significant negative effect of the COVID-19 pandemic measures on the educational development of secondary school students in Calabar South, Cross River State, Nigeria. the study recommends amongst others that the Nigerian government need to copy from other developed nation by partnering with its postal service to deliver worksheets to students in their home especially in low-income families that cannot afford computers.
\end{abstract}

(C) 2021 Author(s). All rights reserved.

Keywords: COVID-19, Pandemic Measures, educational development, education

\section{Introduction}

The novel coronavirus pandemic that has hit the world in the last 8 months is not just a health challenge but has become the greatest catastrophe since the second world war. The pandemic impact has been multifaceted, affecting all sector of human society globally. In the education system of nearly all nations, it has created a large dysfunction affecting nearly 1.6 billion school students globally (United Nations, 2020). As at April 2020, the pandemic has affected 94 per cent of global school students from pre-primary school to secondary schools, technical and vocational training establishments to adult education as well as tertiary education systems in over 200 countries worldwide (ALSamarrai, Gangwar \& Gala, 2020; United Nation, 2020).

On the $20^{\text {th }}$ March 2020, the Nigerian government through the ministry of education directed the closure of all schools as a precautionary measure aimed at checking the spread of the COVID-19 virus across the nation. (Adeoye, adanikin \& Adanikin, 2020). As of June 2020, all schools have been closed, keeping the children at home and affecting the educational development of 46 billion students throughout the country (EIEWG, 2020). The ripple effect of the pandemic has affected students both at the primary, secondary, and tertiary level, including the educators themselves as academic sessions, have been disrupted.

\footnotetext{
* Corresponding author.

E-mail address: omangta@gmail.com (Thoma Achoda Omang)
} 
In a country where 10.5 million children aged 5 to 16 are not in school and a nation where 40.1 per cent of the citizens are poor. The pandemic has created a gap and has left most children behind in terms of learning (Obiakor \& Adeniran, 2020; Ndem, Angioha \& Dike, 2020; Ofem \& Omang, 2018). The Nigerian educational sector like other sectors of the nation's socio-economic system is correlated to the level of income. Public schools differ from private schools. The private schools are attended by those of higher socioeconomic status, while the public schools are attended by those of low socioeconomic status. In situations where long-distance learning or E-learning is available, children who attend public schools are unable to attend as a result of poor infrastructures, lack of electricity etc. This situation is what the COVID-19 pandemic has brought to the fore.

Studies have shown the extent that the coronavirus has had on educational development. Ogunode (2020) assessed the effect of the COVID-19 pandemic on secondary school academic program. using survey design, data were collected from 80 school teachers. Result revealed that COVID-19 pandemic has affected the school calendar and disrupt the literacy level of students. Aristovnik, Keržič, Ravšelj, Tomaževič and Umek (2020) assessed the impact of COVID19 on higher education students. from the analysis of result collected from 30,383 students from 62 nations, result revealed that the there is a correlation between COVID-19 and educational capabilities of higher education students. This study examines the impact of COVID-19 Pandemic measures on the educational development of secondary school students in Calabar, Cross River State, Nigeria.

\section{Methodology}

\subsection{Settings}

Calabar South, the study area is located in Southern Senatorial District of Cross River state Nigeria. Flanked in the east by the Great Kwa River, in the South by the Atlantic Ocean and the Cross-River Estuary, to the North by Calabar Municipality and the West by the Calabar River. Covering a land area of 264 kilometres, the area is located at longitude $8^{0} 19^{\prime}$ and $8^{0} 21^{\prime}$ east of the Greenwich meridian and latitude $4^{0} 54^{\prime}$ and $4^{0} 58^{\prime}$ north of the equator. Politically, Calabar South is divided into twelve wards. with its administrative headquarters at Anantigha (Ukwayi, Angioha \& Nwagboso, 2018; Enukoha \& Angioha, 2019; Omang, Liu, Eneji, \& Eneji, 2012; Ojong, Iji, \& Angioha, 2019). According to the Last official Census of 2006, the population of the area stands at 191,630 (NPC, 2006). The original inhabitants of Calabar South are Efut, Kwas and the Efiks, but with industrialization and the Area becoming the administrative capital of Cross River state, it is now home to families from other Local government Area, as well as states.

\subsection{Study Methods}

The descriptive survey method was adopted for the study. this method allows the researcher to obtain information on the current status of an issue under investigation as well as describe the relationship between the variables under study (Angioha, Enukoha, Agba \& Ikhizamah, 2020). in using the descriptive research method, a self-developed semistructured questionnaire was used to collect data from the field. The questionnaire contained twelve (12) items developed in a Likert Scale Format.

\subsection{Sampling}

400 samples were used for the study. the 400 hundred samples were drawn from households with children in secondary school in Calabar South Local Government Area. The sample size was arrived at using the Slovin Sample Size Formula. Since there are no available figures of the number of households in Calabar, the population of the area was subjected to Slovin Sample Size Formula;

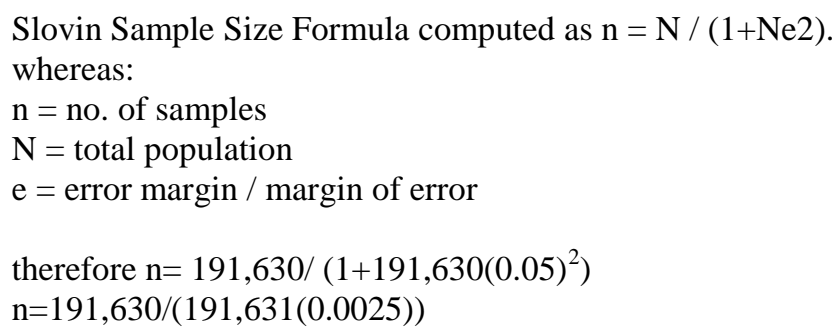




$$
\begin{aligned}
& \mathrm{n}=191,630 / 479.0775 \\
& \mathrm{n}=400
\end{aligned}
$$

In selecting the sample size from the study area, the stratified and purposive sampling technique was adopted. Calabar South was stratified into 12 strata according to the local government of the study area. From the 12 strata, 4 wards were selected using the purposive sampling technique. the wards were selected because of them being predominantly residential areas. The wards selected are ward 11, 9, 12 and 10. From these 4 wards, 4 areas from the selected wards using the purposive sampling technique. From the selected area, the purposive sampling technique was used in selecting 25 households that had children who attended secondary school.

\subsection{Ethical Consideration}

Both written and verbal consent was obtained from the sample used for the study, a letter of consent was attached to the instrument of data collection given to the samples and the researcher obtained verbal approval from the samples. The researchers explained the process of the research to the samples and the anonymity of the information provided was assured.

\subsection{Data collection and Analysis}

The data was collected in a three weeks period with the aid of five (5) research assistants, who were trained on the ethics of research data collection process. Data collected from the field was analyzed using descriptive statistics. This includes frequency distribution, simple percentages and graphical illustration. The result from the descriptive analysis was then subjected to parametric statistics (simple Lineal Regression) at 0.05 level of significance. Out of the 400instrument distributed, only 379 was returned without being mutation or missing and was used for analysis

\section{Findings and Discussion}

\subsection{Descriptive analysis of the result}

The objective of the study is to analyze the impact of the COVID-19 Pandemic measures on the educational development of Secondary School Students in Calabar South, Cross River State, Nigeria. The research instrument used to collect data from the samples was rases based on the objectives of the study. data analysis was done using descriptive statistics before the result was subjected to parametric statistics

Table 1. Response to COVID-19 pandemic measures and educational development

\begin{tabular}{llll}
\hline S/N & Item & Public school & Private school \\
\hline 1 & What school do you attend & $224(59.01 \%)$ & $155(40.90)$ \\
\hline
\end{tabular}

Source: Field survey, 2020

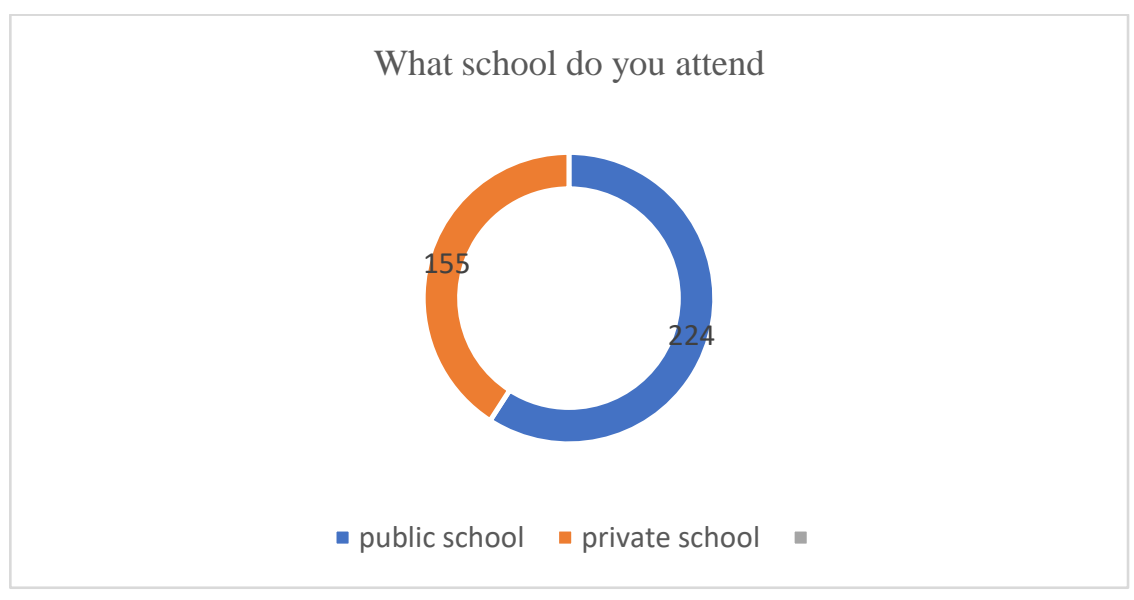

Fig. 1. The school sample attends 
Table 2. Response to COVID-19 pandemic measures and educational development

\begin{tabular}{llcc}
\hline S/N & Items & Yes & No \\
\hline 2 & During the closing of schools as a result of the lockdown, where you & $97(25.59 \%)$ & $282(74.41 \%)$ \\
& home school by your parents & & \\
3 & Was a lesson teacher paid to give you lessons during the lockdown & $121(31.93 \%)$ & $258(68.07 \%)$ \\
4 & Did you take lesson from your school on zoom or Microsoft team & $7(1.85 \%)$ & $372(98.15 \%)$ \\
5 & Did your school send you home assignments during the lockdown & 0 & $379(100.00 \%)$ \\
\hline
\end{tabular}

Source: Field survey, 2020

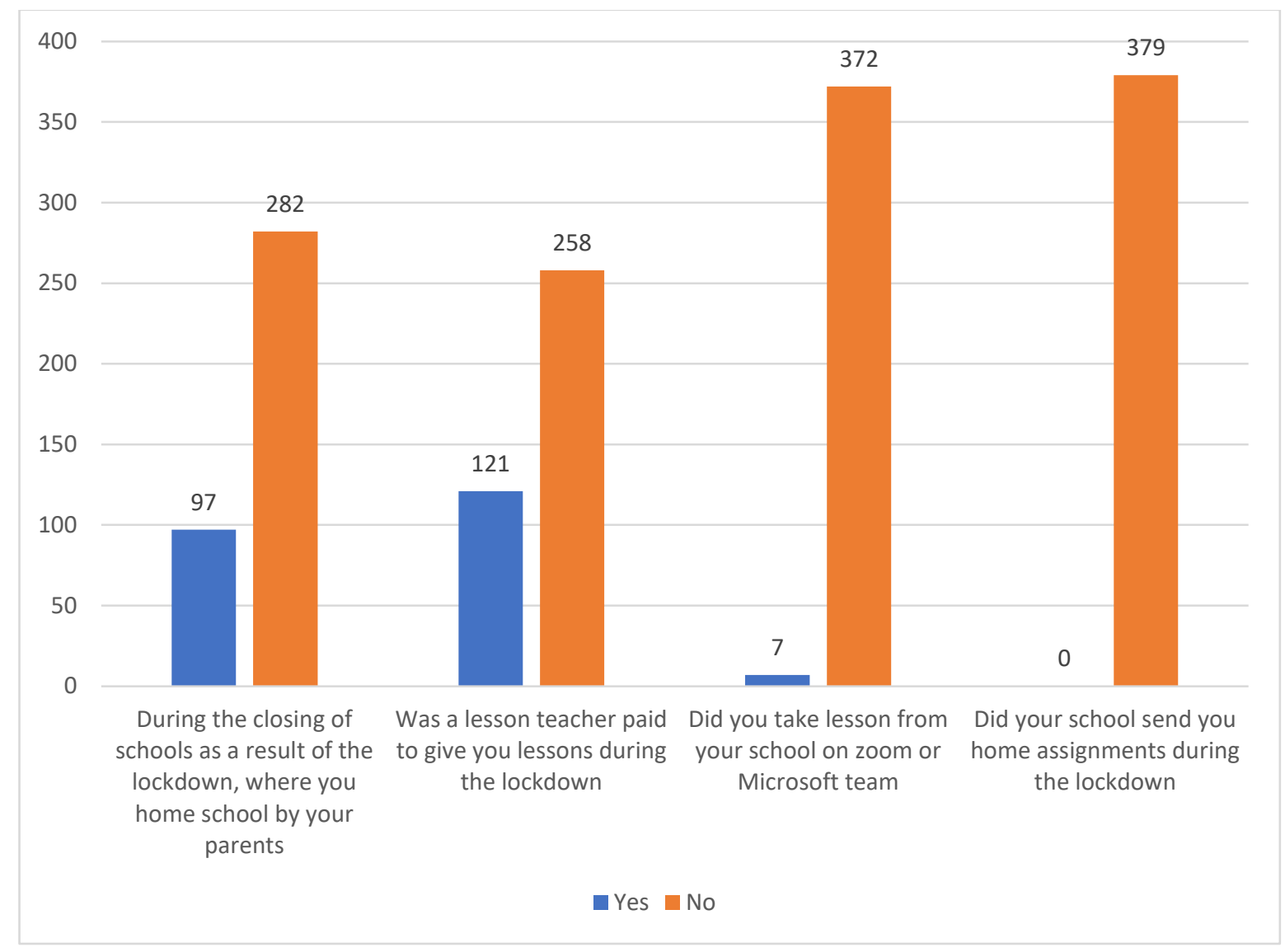

Fig. 2. Response on COVID-19 pandemic measures and educational development

Table 3. Response to COVID-19 pandemic measures and educational development

\begin{tabular}{llcccc}
\hline S/N & Items & Every day & $\begin{array}{c}\text { Three times a } \\
\text { week }\end{array}$ & $\begin{array}{c}\text { ones every } \\
\text { week }\end{array}$ & none \\
\hline 6 & How often were you homeschooled & $12(3.17 \%)$ & $117(30.87 \%)$ & $89(23.48 \%)$ & 161 \\
& & & & $(42.48 \%)$ \\
7 & How often did you read your books & $28(7.39 \%)$ & $161(42.48 \%)$ & $72(18.99 \%)$ & 118 \\
& & & & $(31.13 \%)$ \\
\hline
\end{tabular}

Source: Field survey, 2020 


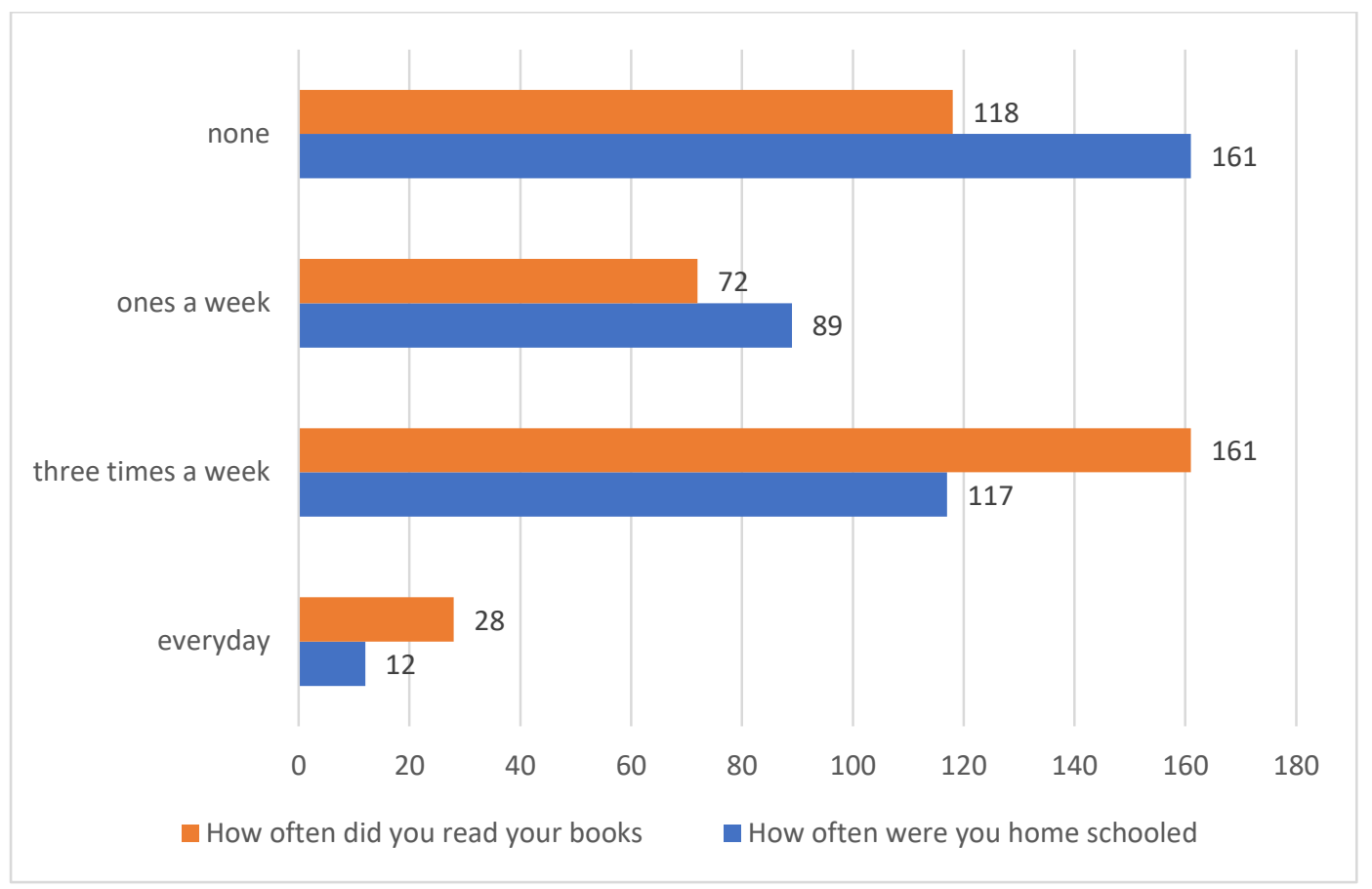

Fig. 3. Response on COVID-19 pandemic measures and educational development

Table 4. Response to COVID-19 pandemic measures and educational development

\begin{tabular}{|c|c|c|c|c|}
\hline $\mathrm{S} / \mathrm{N}$ & Item & Yes & No & Not sure \\
\hline 8 & $\begin{array}{l}\text { Do you still remember what you were last taught in school } \\
\text { before the lockdown }\end{array}$ & $206(54.35 \%)$ & $141(37.20 \%)$ & $\begin{array}{c}32 \\
(8.44 \%)\end{array}$ \\
\hline
\end{tabular}

Source: Field survey, 2020

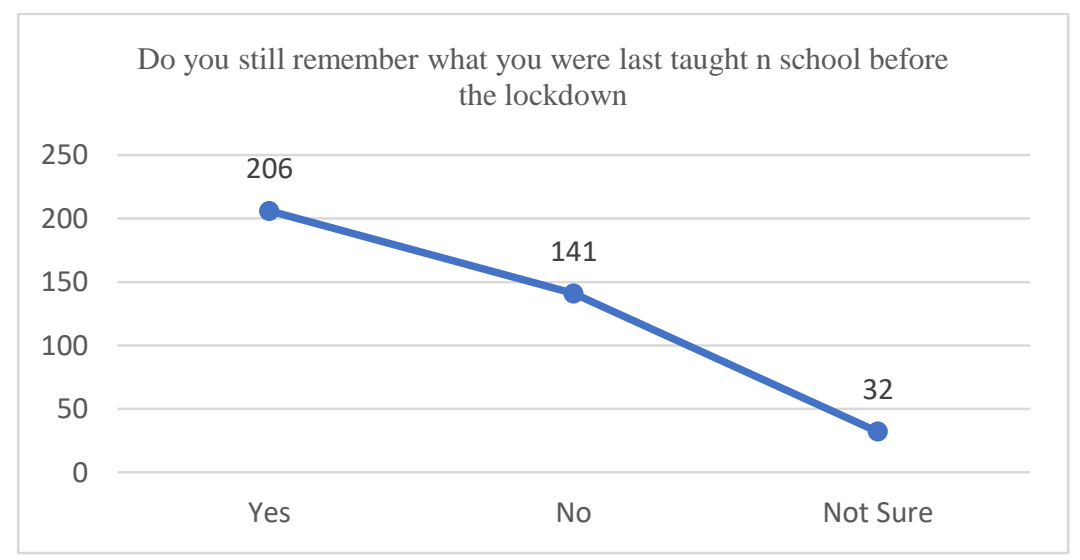

Fig. 3. Response on COVID-19 pandemic measures and educational development

Results of descriptive analysis as presented in table 1 to 4 with graphical illustration from fig. 1 to 4 shows respondents response pattern as follows; What school do you attend; $224(59.01 \%)$ reported public schools and 155 (40.90) reported private schools. On during, the closing of schools as a result of the lockdown, where you home 
school by your parents; 97 (25.59\%) reported Yes, while $282(74.41 \%)$ reported No. On Was a lesson teacher paid to give you lessons during the lockdown; 121 (31.93\%) reported Yes, while 258 (68.07\%) reported No. On did you take lessons from your school on zoom or Microsoft team: 7 (1.85\%) samples reported Yes, while $372(98.15 \%)$ reported No. On did your school send you home assignments during the lockdown; all the samples, 379 (100.00\%) reported No. On How often were you homeschooled: 12 (3.17\%) samples reported every day, 117 (30.87\%), reported three times a week, $89(23.48 \%)$ reported ones a week, and $161(42.48 \%)$ reported there were not homeschooled. On How often did you read your book: 28 (7.39\%) samples reported every day, $161(42.48 \%)$ reported three times a week, $72(18.99 \%)$ reported ones a week and $118(31.13 \%)$ reported not reading at all. On Do you still remember what you were last taught in school before the lockdown; 206 (54.35\%) reported yes, $141(37.20 \%)$ reported No and $32(8.44 \%)$ reported not sure.

\subsection{Parametric statistics}

The result from the descriptive statistics was then subjected to Pearson Product Moment Correlation at 0.05 confidence level. In this analysis, the independent variable Covid 19 pandemic measures while the dependent variable is educational development. Pearson product-moment correlation coefficient was used to test this hypothesis at 0.05 level of significance and the result is presented in Table

Table 7. Pearson product moment correlation of use of COVID-19 pandemic measures and educational development

\begin{tabular}{|c|c|c|c|c|c|}
\hline Variable & $\mathrm{N}$ & Mean & SD & r-value & Sig. \\
\hline COVID-19 pandemic measures & 379 & 16.72 & 1.91 & \multirow[b]{2}{*}{$0.355^{*}$} & \multirow[b]{2}{*}{0.000} \\
\hline educational development & 379 & 12.07 & 1.95 & & \\
\hline
\end{tabular}

*significant at 0.05 level; $\mathrm{df}=377$ critical $\mathrm{r}$ value $=0.098$

Source: Field survey, 2020

The result in Table 7 revealed that the calculated $r-$ value of $0.355^{*}$ is greater than the critical $r$-value of 0.098 at 0.05 level of significance with 377 degrees of freedom. By this result, there is a significant correlation between COVID-19 pandemic measures and educational development. The correlation coefficient is a standardized measure of an observed effect, it is a commonly used measure of the size of an effect and that values of \pm .1 represent a small effect, \pm .3 is a medium effect and \pm .5 is a large effect. The squared correlation $(0.355)^{2}$ which is a measure of effect size indicates the proportion of explained variance on the dependent variable. Therefore, $12.6 \%$ of the variance in the educational development of secondary school students is accounted for by COVID-19 pandemic measures. The magnitude of the effect is moderate, this means that the COVID-19 pandemic measures have had a negative effect on the educational development of secondary school students in Calabar South. Therefore, we can conclude that there is a statistical considerable relationship between COVID-19 pandemic measures and educational development of secondary school students in Calabar South Local Government Area of Cross River State, Nigeria.

\subsection{Discussion of Findings}

From the analysis of the data analyzed using descriptive statistics, it was discovered that 59.01 per cent of the respondents attend public schools, while 40.90 per cent of them attend private schools. This is true because the study area is mostly rural and most people living there are poor and cannot afford to send their children to exclusive private schools. The result also revealed that parents also contributed to the no educational development of their children, as 74.41 per cent of the respondents reported that their parents did not take time out to teach them during the lockdown period. Result also revealed that most of the children, 68.07 per cent did not take lessons during the lockdown period. This can be attributed to the fact that most of the parents could hardly afford to provide for the family during the lockdown, so could not afford to pay for lessons for their children or wards.

The result from the analysis also revealed that 98.15 per cent of the respondents did not take part in any online lessons organized by their school. This is true because most public schools are not equipped or staffed to run an online program for their students. Most of the public run schools in the study area do not have teachers that are trained or equipped to carry out E-learning programs. Result also revealed that all the respondents reported that their schools did not send them assignments to keep them busy during the lockdown. 31.13 per cent of the respondents reported that they never read their books during the lockdown, while 42.48 per cent reported that they were forced to 
read their books by their parents at least three times a week. A small majority, 54.35 per cent of the respondents reported that they can still remember what they were taught, while 37.20 per cent reported that they can hardly remember what they were taught before the lockdown.

From the correlation analysis carried out using Pearson Product Moment Correlation Analysis, Result revealed that there is a significant correlation between COVID-19 pandemic measures and educational development. This is because the calculated $\mathrm{r}-$ value of $0.355^{*}$ is greater than the critical $\mathrm{r}$-value of 0.098 at 0.05 level of significance with 377 degrees of freedom. Also, the squared correlation $(0.355)^{2}$ which is a measure of effect size indicates the proportion of explained variance on the dependent variable, hence $12.6 \%$ of the variance in the educational development of secondary school students is accounted for by COVID-19 pandemic measures. With this result we can conclude that there is a statistical considerable relationship between COVID-19 pandemic measures and educational development of secondary school students in Calabar South Local Government Area of Cross River State, Nigeria.

\section{Conclusion and Policy Implication}

This study has shown that the COVID-19 pandemic has had an obvious effect on the educational system and the educational development of school students. The pandemic has not only affected but has brought to the fore the problems that are inherent in our education system in Nigeria. On a brighter note, it has served as the change agent for promoting the much-heralded E-learning system adopted by other advance countries as well as the need for change in the educational curriculum. Thus, it is recommended that the government and its agencies in charge of education in the country need to adopt an E-learning platform that will complement the classroom learning. This will help in times of crisis such as these. The Nigerian government need to copy from other developed nation by partnering with its postal service to deliver worksheets to students in their home especially in low-income families that cannot afford computers.

\section{References}

Adeoye, I. A., Adanikin, A. F. \& Adanikin, A. (2020). COVID-19 and E-Learning: Nigeria Tertiary Education System Experience. International Journal of Research and Innovation in Applied Science (IJRIAS), 5(5), 2831

Al-Samarrai, S., Gangwar, M. \& Gala, P. (2020). The Impact of the COVID-19 Pandemic on Education Financing. Economic Impact of COVID-19. World Bank, Washington. https://openknowledge.worldbank.org/handle/10986/33739

Angioha, P. U., Enukoha, C. U., Agba, R. U., \& Ikhizamah, G. U. (2020). Information Technology Predictor Variables and Employee Productivity in Commercial Banks. JINAV: Journal of Information and Visualization, 1(1), 44-52. https://doi.org/10.35877/454RI.jinav178

Aristovnik, A., Keržič, D., Ravšelj, D., Tomaževič, N. \& Umek, L. (2020). Impacts of the COVID-19 Pandemic on Life of Higher Education Students: A Global Perspective. Sustainability 2020, 12, 8438.

Deborah, J. (2020) Perception of Undergraduate Students on the Impact of COVID-19 Pandemic on Higher Institutions Development in Federal Capital Territory Abuja, Nigeria, Electronic Research Journal of Social Sciences and Humanities Vol 2: Issue II ISSN: 2706 - 8242 www.eresearchjournal.com Apr-Jun 2020

Enukoha, C. U. \& Angioha, P. U. (2019)."Management Support for the Use of Information technology in Commercial Banks in Cross River State, Nigeria: Examining Its Relationship with the Productivity of Workers", Journal of Banking and Finance Management, 2(3), pp.1-7

Ndem, M. A., Angioha, P. U. \& Dike, E. (2020). Improving the Socio-Economic Wellbeing of Rural People: Analysis of the Impact of the Community and Social Development Project (CSDP) tn Odukpani Local Government Area of Cross River State, Nigeria. Asian Journal of Applied Sciences.8 (2), 88-94. 
Obiakok, T. \&Adeniran, A. (2020). COVID-19: Impending Situation Threatens to Deepen Nigeria's Education Crisis. https://media.africaportal.org/documents/COVID19-Impending-Situation-Threatens-to-Deepen-NigeriasEducation-.pdf

Ofem, N. O. \& Omang, T. A. (2018). Empirical Analysis of Poverty and Well-Being of Rural Dwellers in Yakurr Local Government Area of Cross River State, Nigeria. European Journal of Social Sciences Studies. 3 (2), 126-137.

Ogunode, N, J. (2020) Effects of COVID-19 Schools Close Down on Academic Programme of Senior Secondary Schools in Abaji Area Council of Federal Capital Territory Abuja, Nigeria. Electronic Research Journal of Social Sciences and Humanities Vol 2: Issue II ISSN: 2706 - 8242 www.eresearchjournal.com Apr-Jun 2020

Ojong, M. U., Iji, M. E. \& Angioha, P.U. (2019). Curing Socio-Economic ILLS in Obudu Local Government Area: An Assessment of Non-Governmental Agencies Activities. Journal of Social Service and Welfare;1(2): 3845 .

Omang, T. A., Liu, Y ., Eneji, M. A. \& Eneji, C. V. O. (2012).Cash cropping as an effective strategy for rural poverty reduction in Nigeria: the case of cocoa farming in Etung, Cross River State. Journal of Agriculture, Biotechnology and Ecology.5 (3) pp.83-93.

The Nigeria Education Working Group (EiEWG). (2020). Nigeria Education Sector COVID19 Response Strategy in North East. https://reliefweb.int/sites/reliefweb.int/files/resources/nigeria_education_sector_COVID19 response_strategy north east_pdf

Ukwayi J. K. (Ph.D), Angioha P .U. \& Nwagboso S. N. (2018). Poverty and Insecurity: A Dangerous Threat to Business Activities and Development in Calabar South LGA, Cross River State, Nigeria. SSRG International Journal of Humanities and Social Science 5(2), 33-38.

United Nation (2020). Policy Brief: Education during COVID-19 and beyond. https://www.un.org/development/desa/dspd/wpcontent/uploads/sites/22/2020/08/sg_policy brief_COVID19 and education august 2020.pdf 